\title{
MENINGKATKAN KEMAMPUAN GURU YANG TELAH DISERTIFIKASI DALAM MENYUSUN RENCANA PELAKSANAAN PEMBELAJARAN MELALUI BIMBINGAN BERKELANJUTAN PADA SEKOLAH BINAAN DI SAMBAS
}

\author{
Oleh \\ Lili Ng Chui Mi ${ }^{1}$
}

\begin{abstract}
Abstrak : Pada kenyataan di sekolah, masih banyak ditemukan guru yang telah disertifikasi belum bisa membuat RPP sesuai dengan ketentuan. Penelitian ini bertujuan: meningkatkan motivasi dan kemampuan guru yang telah disertifikasi dalam menyusun RPP sesuai standar. Metode penelitian yang digunakan adalah metode kuantitatif dengan bentuk pendekatan deskriptif, menggunakan teknik persentase untuk melihat peningkatan dari siklus pertama sampai siklus ke ketiga, yang meliputi kegiatan-kegiatan; (1) perencanaan, (2) pelaksanaan, (3) observasi dan (4) refleksi. Hasil penelitian menunjukkan bahwa, melalui bimbingan berkelanjutan dapat meningkatkan motivasi dan kemampuan guru dalam menyusun RPP.
\end{abstract}

Kata kunci: Kemampuan guru, RPP, Bimbingan berkelanjutan.

Dalam rangka mencapai tujuan pendidikan nasional yaitu mencerdaskan kehidupan bangsa dan pengembangan manusia Indonesia seutuhnya, maka sangat dibutuhkan peran pendidik ( terutama guru) yang profesional sesuai dengan Undang-Undang Republik Indonesia No.20 Tahun 2003 tentang Sistem Pendidikan Nasional menyatakan "jabatan atau profesi guru sebagai pendidik merupakan salah satu jabatan profesional". Selanjutnya profesionalisme guru

dituntut agar terus berkembang sesuai dengan IPTEK serta kebutuhan masyarakat

termasuk kebutuhan terhadap pendidikan yang akan menghasilkan lulusan sumber

daya manusia yang berkualitas dan mampu memiliki kapabilitas untuk mampu bersaing baik diforum regional, nasional maupun internasional.

Di antara komponen-komponen sistem pendidikan, sumber daya manusia yang selama ini mendapat perhatian lebih banyak adalah tenaga

\footnotetext{
${ }^{1}$ Lili Ng Chui Mi adalah Pengaswas Sekolah Kabupaten Sambas
} 
guru. Besarnya perhatian terhadap guru antara lain dapat dilihat dari banyaknya kebijakan khusus seperti kenaikan tunjangan fungsional guru dan sertifikasi guru.

Berbagai usaha untuk mempersiapkan guru telah diupayakan sedemikian rupa, pada kenyataan ditunjukkan bahwa tidak semua guru memiliki kinerja yang baik dalam melaksanakan tugasnya. Hal itu ditunjukkan dengan kenyataan: (1) guru sering mengeluh kurikulum yang berubah-ubah, (2) guru sering mengeluhkan kurikulum yang syarat dengan beban, (3) seringnya siswa mengeluh dengan cara mengajar guru yang kurang menarik, (4) masih belum dapat dijaminnya kualitas pendidikan sebagai mana mestinya ( Ali Imron, 2000:5).

Direktorat Pembinaan SMA (2008:3) menyatakan "kualitas pendidikan sangat ditentukan oleh kemampuan sekolah dalam mengelola proses pembelajaran, dan lebih khusus lagi adalah proses pembelajaran yang terjadi di kelas, mempunyai andil dalam menentukan kualitas pendidikan konsekuensinya, adalah guru harus mempersiapkan (merencanakan ) segala sesuatu agar proses pembelajaran di kelas berjalan dengan efektif'.

Perencanaan merupakan langkah yang sangat penting sebelum pelaksanaan kegiatan belajar mengajar (KBM), membutuhkan perencanaan yang matang agar berjalan secara efektif. Perencanaan KBM dituangkan kedalam Rencana Pelaksanaan Pembelajaran (RPP) atau beberapa istilah lain seperti desain pembelajaran, skenario pembelajaran. RPP memuat seluruh $\mathrm{KD}$, indikator yang akan dicapai, materi yang akan dipelajari, langkah pembelajaran, waktu, media dan sumber belajar serta penilaian untuk setiap KD.

Guru harus mampu berperan sebagai desainer (perencana), implementor (pelaksana), dan evaluator (penilai) kegiatan pembelajaran. Guru merupakan faktor yang paling dominan, karena di tangan gurulah keberhasilan pembelajaran dapat dicapai. Kualitas mengajar guru secara langsung maupun tidak langsung dapat mempengaruhi kualitas pembelajaran pada umumnya.

Penelitian Tindakan Sekolah ini, ditujukan pada guru yang telah disertifikasi. Adapun alasan peneliti memilih guru yang telah disertifikasi adalah guru yang dianggap bermutu dan sudah memenuhi standar profesional, dimana guru yang bersangkutan telah mengikuti sertifikasi untuk memperoleh sertifikat pendidik. Sertifikasi merupakan sarana atau instrumen untuk meningkatkan kualitas kompetensi guru. Sertifikasi bukan tujuan, melainkan sarana untuk mencapai suatu tujuan, yaitu keberadaan guru yang berkualitas.

Kumaidi. 2008. (Http://massofa.wordpress.com) menjelaskan sertifikasi adalah proses pembuktian bahwa seorang guru telah 
memenuhi persyaratan yang ditentukan oleh peraturan perundangundangan.

Selanjutnya UU Guru dan Dosen No.14 Tahun 2005 pasal 1 butir 12 mengatakan "Sertifikasi adalah proses pemberian sertifikat pendidik untuk guru. Sertifikat pendidik adalah bukti formal sebagai pengakuan yang diberikan kepada guru sebagai tenaga profesional. Sertifikat pendidik merupakan bukti formal sebagai pengakuan yang diberikan kepada guru sebagai tenaga profesional. Selanjutnya pasal 8 memuat tentang "guru wajib memiliki kualifikasi akademik, kompetensi, sertifikat pendidik, sehat jasmani dan rohani, serta memiliki kemampuan untuk mewujudkan tujuan pendidikan nasional".

Berdasarkan beberapa definisi di atas dapat disimpulkan sertifikasi guru adalah proses pemberian sertifikat pendidik kepada guru yang memiliki kompetensi, sehat jasmani dan rohani, serta memiliki kemampuan untuk mewujudkan tujuan pendidikan nasional.

Sebagaimana ketentuan dalam Peraturan pemerintah Nomor 19 (2005) tentang delapan Standar Nasional Pendidikan menyatakan salah satunya adalah standar proses untuk satuan pendidikan dasar dan menengah mencakup: 1) Perencanaan proses pembelajaran, 2) Pelaksanaan proses pembelajaran, 3) Penilaian hasil pembelajaran, 4) dan pengawasan proses pembelajaran. Dari keempat komponen tersebut salah satunya adalah perencanaan proses pembelajaran meliputi Silabus dan Rencana Pelaksanaan Pembelajaran (RPP). Silabus dan RPP dikembangkan oleh guru masingmasing pada satuan pendidikan. Guru pada satuan pendidikan berkewajiban menyusun Silabus dan RPP secara lengkap dan sistematis agar pembelajaran berlangsung secara interaktif, inspiratif, menyenangkan, menantang, memotivasi peserta didik untuk berpartisipasi aktif, serta memberikan ruang yang cukup bagi prakarsa, kreativitas dan kemandirian sesuai dengan bakat, minat dan perkembangan fisik serta psikologis peserta didik. Selanjutnya pasal 20 menyatakan bahwa " RPP minimal memuat sekurang-kurangnya lima komponen yang meliputi: (1) tujuan pembelajaran, (2) materi ajar, (3) metode pengajaran, (4) sumber belajar, dan (5) penilaian hasil belajar.

Masalah yang terjadi di lapangan masih ditemukan adanya guru yang telah disertifikasi tidak bisa memperlihatkan RPP yang dibuat, dengan alasan ketinggalan ditempat sekolah lain tempat guru tersebut mengajar, dan bagi guru yang sudah membuat RPP masih terdapat ada guru yang belum melengkapi komponen tujuan pembelajaran dan penilaian (soal, skor dan kunci jawaban), hal itu diketahui pada saat peneliti mengadakan observasi terhadap RPP yang dibuat oleh guru yang telah disertifikasi.

Dengan keadaan demikian, peneliti sebagai pembina sekolah berusaha untuk memberi bimbingan berkelanjutan pada guru yang telah disertifikasi dalam menyusun RPP dengan lengkap, sesuai dengan tuntutan 
pada Standar Proses dan Standar Penilaian yang merupakan bagian dari Standar Nasional Pendidikan. Hal itu juga sesuai dengan Tupoksi peneliti sebagai pengawas sekolah berdasarkan Permendiknas No.12 Tahun 2007b Tentang enam standar Kompetensi pengawas sekolah salah satunya adalah supervisi akademik yaitu membina guru.

Rencana Pelaksanaan Pembelajaran harus dibuat agar kegiatan pembelajaran berjalan sistematis dan mencapai tujuan pembelajaran, tanpa rencana pelaksanaan pembelajaran kegiatan pembelajaran di kelas biasanya tidak terarah, sehingga menyebabkan ada SK dan KD yang tidak tersampaikan.

Permendiknas No.41 Tahun 2007a mengatakan "Rencana Pelaksanaan Pembelajaran" adalah rencana yang menggambarkan prosedur dan pengorganisasian pembelajaran untuk mencapai satu kompetensi dasar yang ditetapkan dalam standar isi dan telah dijabarkan dalam silabus.

Menurut Philip Combs ( dalam Kurniawati, 2009:66 ) mengatakan bahwa perencanaan program pembelajaran merupakan suatu penetapan yang memuat komponen-komponen pembelajaran secara sistematis. Analisis sistematis merupakan proses perkembangan pendidikan yang akan mencapai tujuan pendidikan agar lebih efektif dan efisien disusun secara logis, rasional, sesuai dengan kebutuhan siswa, sekolah, dan daerah (masyarakat). Perencanaan program pembelajaran adalah hasil pemikiran, berupa keputusan yang akan dilaksanakan .

Berdasarkan pendapat di atas dapat disimpulkan perencanaan pelaksanaan pembelajaran adalah suatu upaya menyusun perencanaan pembelajaran yang akan dilaksanakan dalam kegiatan pembelajaran untuk mencapai tujuan yang telah ditetapkan dalam kurikulum sesuai dengan kebutuhan siswa, sekolah dan daerah.

\section{MASALAH.}

1. Apakah dengan melalui bimbingan berkelanjutan dapat memotivasi guru yang telah disertifikasi dalam menyusun RPP ?

2. Apakah dengan melalui bimbingan berkelanjutan dapat meningkatkan kemampuan guru yang telah disertifikasi dalam menyusun RPP ?

\section{RENCANA PEMECAHAN MASALAH/TINDAKAN.}

Masalah yang pertama yaitu: Peneliti mencoba untuk mengambil tindakan dengan memberi penjelasan dan bimbingan berkelanjutan kepada guru tentang pentingnya seorang guru membuat RPP secara lengkap, selanjutnya peneliti menyiapkan format penilaian kecakapan hidup dan sikap yang nantinya akan diisi oleh peneliti, setelah peneliti melihat sikap guru saat mendengarkan penjelasan peneliti tentang RPP. Berikutnya peneliti 
menyiapkan angket yang berhubungan dengan motivasi yang diisi oleh guru. Dengan bimbingan berkelanjutan diharapkan guru termotivasi dalam menyusun RPP dengan lengkap dan dapat digunakan sebagai panduan dalam mengajar, agar SK dan KD yang terdapat dalam standar isi dapat tersampaikan semua, karena sudah ada dalam RPP yang dibuat oleh guru. Untuk lebih jelasnya dapat dilihat pada siklus dua.

Masalah yang kedua yaitu: Peneliti mencoba melihat proses peningkatan kemampuan guru dalam menyusun RPP melalui instrument proses yang telah dirancang yaitu berupa lembar observasi/pengamatan komponen RPP yang memuat lima komponen yaitu 1) tujuan pembelajaran, 2) materi ajar, 3) metode pembelajaran, 4) sumber belajar dan 5) penilaian hasil belajar (Soal, kunci dan skor), untuk melihat apakah guru yang sudah disertifikasi sudah membuat RPP dengan lengkap. Hal itu nanti akan dibuktikan dengan melihat RPP yang dibuat oleh guru pada siklus dua dan siklus tiga apakah terjadi peningkatan.

\section{TUJUAN}

1. Untuk meningkatkan Motivasi guru yang telah disertifikasi dalam menyusun Rencana Pelaksanaan Pembelajaran dengan lengkap.

2. Untuk meningkatkan kemampuan guru yang telah disertifikasi dalam menyusun Rencana Pelaksanaan Pembelajaran secara lengkap.

\section{MANFAAT}

Manfaat Penelitian bagi peneliti yaitu: (1) Meningkatkan kemampuan peneliti, dalam menyusun serta menulis laporan dan artikel ilmiah, (2) Hasil penelitian ini digunakan peneliti sebagai evaluasi terhadap guru yang telah disertifikasi dalam menyusun RPP yang selanjutnya akan digunakan sebagai bahan pembinaan guru di sekolah binaan. Bagi sekolah: (1) akan berdampak adanya peningkatan administrasi guru pada KBM yang lebih lengkap, (2) Dapat meningkatkan kualitas pendidikan, karena Standar Kompetensi dan Kompetensi Dasar sudah tersampaikan. Bagi guru: (1) dapat meningkatkan kemampuan dalam membuat RPP dengan lengkap , serta menciptakan kesadaran guru tentang tanggungjawabnya terhadap pelaksanaan tugasnya,(2) sebagai panduan dalam mengajar, sehinga apa yang diinginkan dalam standar isi dapat tersampaikan. Bagi siswa yaitu: (1) adanya kesiapan belajar, keseriusan , keingintahuan dan semangaat belajar tinggi terhadap pelajaran, (2) lebih percaya diri dalam mengikuti proses belajar mengajar, sehingga tercapai target kompetensinya.

\section{METODE PENELITIAN TINDAKAN}

1. Setting Penelitian yaitu : (1)Tempat Penelitian, (a) SMPN. 3 Tebas 3 orang, (b) SMPN. 1 Tekarang 6 orang, (c) SMPN 3. Semparuk terdiri 4 
orang, (d) SMPN. 2 Pemangkat 7 Orang, (e) SMPN 5 Sambas 6 orang dan (f) SMPN. 1 Tebas 4 orang. (2) Waktu penelitian selama 4 bulan mulai September sampai dengan Desember 2009, (3) siklus penelitian melalui tiga siklus.

2. Persiapan PTS yaitu: Sebelum PTS dilaksanakan dibuat berbagai input instrument yang digunakan untuk mendapatkan data dan informasi.

3. Subjek Penelitian adalah guru SMP yang telah disertifikasi pada tahun 2007 dan tahun 2008 di kabupaten Sambas.

4. Sumber Data adalah Rencana Pelaksanaan Pembelajaran yang sudah dibuat guru SMP yang telah disertifikasi di Kabupaten Sambas.

\section{Teknik dan Alat Pengumpulan Data}

Teknik pengumpulan data dalam penelitian ini yakni: (1) Wawancara dipergunakan untuk mendapatkan data atau informasi tentang pemahaman guru tentang RPP, (2) Skala Sikap digunakan oleh peneliti untuk mengetahui sikap guru, saat peneliti menjelaskan/berdiskusi tentang Rencana Pelaksanaan Pembelajaran (RPP), (3) Angket digunakan untuk melihat motivasi guru, (4) Observasi dipergunakan untuk mengumpulkan data dan melihat kemampuan guru dalam menyusun Rencana Pelaksanaan Pembelajaran dengan lengkap, (5) diskusi dilakukan antara peneliti dengan guru.

Alat pengumpulan data dalam PTS ini meliputi, wawancara, skala sikap, angket, observasi dan diskusi sebagai berikut, (1) Wawancara menggunakan panduan wawancara untuk mengetahui kemampuan awal yang dimiliki guru tentang RPP, (2) Skala Sikap menggunakan format penilaian kecakapan hidup dan sikap, (3) Angket menggunakan pertanyaan yang berhubungan dengan motivasi, (4) Observasi menggunakan lembar observasi untuk mengetahui komponen RPP yang telah dibuat dan yang belum dibuat oleh guru, (5) Diskusi dilakukan dengan maksud untuk sharing pendapat antara peneliti dengan guru .

\section{Prosedur penelitian}

Metode penelitian yang peneliti gunakan adalah metode kuantitatif dalam bentuk pendekatan deskriptif, dengan menggunakan teknik persentase untuk melihat peningkatan yang terjadi dari siklus ke siklus. Dengan metode ini peneliti berupaya menjelaskan data yang peneliti kumpulkan melalui komunikasi langsung atau wawancara, skala sikap, angket, observasi/pengamatan, dan diskusi.

Hal-hal penting yang harus diperhatikan dalam Penelitian Tindakan Sekolah, menurut Sudarsono, F.X, (1999:2) yakni: (1) rencana yakni: Tindakan apa yang akan dilakukan untuk meningkatkan kemampuan guru dalam menyusun RPP secara lengkap. Solusinya yaitu dengan melakukan: a) 
wawancara dengan guru, dengan menyiapkan lembar wawancara, b) Diskusi dalam suasana yang menyenangkan dan c) memberikan bimbingan dalam menyusun RPP secara lengkap, (2) pelaksanaan: Apa yang dilakukan oleh peneliti sebagai upaya meningkatkan kemampuan guru dalam menyusun RPP yang lengkap yaitu dengan memberikan bimbingan berkelanjutan pada guru, (3) Observasi: peneliti melakukan pengamatan terhadap RPP yang telah dibuat, guna untuk memotret seberapa jauh kemampuan guru dalam menyusun RPP dengan lengkap. hasil atau dampak dari tindakan yang telah dilaksanakan dalam mencapai sasaran. Rekaman dari pertemuan dan wawancara akan digunakan untuk analisis dan komentar kemudian dan (4) Refleksi yakni : Peneliti mengkaji, melihat dan mempertimbangkan hasil atau dampak dari tindakan yang telah dilakukan. Berdasarkan hasil dari refleksi ini, peneliti bersama guru melaksanakan revisi atau perbaikan terhadap RPP.

Prosedur penelitian adalah suatu rangkaian tahap-tahap penelitian dari awal sampai akhir. Penelitian ini merupakan proses pengkajian sistem berdaur sebagaimana kerangka berpikir yang dikembangkan oleh Suharsimi Arikunto, dkk. (2006:74). Prosedur ini mencakup tahap-tahap: (1) perencanaan, (2) pelaksanaan, (3) pengamatan, dan (4) refleksi. Keempat kegiatan tersebut saling terkait dan secara urut membentuk sebuah siklus. PTS merupakan penelitian yang bersiklus. Artinya penelitian dilakukan secara berulang dan berkelanjutan sampai tujuan penelitian dapat tercapai.

\section{HASIL DAN PEMBAHASAN PENELITIAN}

\section{A. Deskripsi Hasil Penelitian}

Dari hasil wawancara dan observasi peneliti dengan guru yang telah disertifikasi tentang Rencana Pelaksanaan Pembelajaran, ternyata masih ada satu guru belum bisa menunjukkan RPP yang dibuat, dan bagi guru yang sudah menyusun RPP masih ada komponen yang kurang lengkap yaitu pada komponen tujuan pembelajaran dan komponen penilaian ( soal, skor dan kunci jawaban). Adapun alasan tidak dibuat lengkap pada komponen penilaian, pada saat peneliti tanya , jawabannya sudah tahu dan ada dikepala.

Setelah mendengar penjelasan dari peneliti bahwa antara soal, penskoran dan kunci jawaban merupakan satu kesatuan, pada prinsifnya ketiga puluh orang guru tersebut setuju RPP dibuat dengan lengkap.

Disamping itu dilihat dari sikap guru sangat antusias/termotivasi untuk melengkapi komponen yang ada dalam RPP, ini dapat dilihat dari perolehan skor motivasi yang diisi oleh guru. Selanjutnya kalau dilihat dari sikap guru yang telah disertifikasi menunjukkan keingintahuan yang tinggi 
untuk memahami RPP, hal itu dapat dilihat dari format penilaian kecakapan hidup yang rata-rata nilainya 89,94 berkategori baik .

Dilihat dari segi kemampuan guru yang telah disertifikasi terjadi peningkatan dalam menyusun RPP dari sikkus ke siklus .

\section{B. PEMBAHASAN}

Penelitian dilaksanakan pada enam Sekolah Menengah Pertama binaan peneliti di Kabupaten Sambas, terdiri dari 30 orang guru yang telah disertifikasi tahun 2007 dan 2008, dilaksanakan dalam tiga siklus. Adapun Komponen-komponen keberhasilan yang dicapai dalam penelitian ini adalah dari ketiga puluh orang guru tersebut menunjukkan sikap yang baik dan termotivasi dalam menyusun RPP dengan lengkap , hal itu dapat dilihat dari uraian di bawah ini.

Berdasarkan format penilaian kecakapan hidup dan sikap sebanyak 11 aspek yang berkaitan dengan kecakapan personal dan kecakapan sosial, ketiga puluh guru tersebut, menurut pengamatan peneliti menunjukkan sikap yang baik dan merespon RPP dibuat dengan lengkap, ini dapat dilihat dari aspek keaspek bahwa 24 guru berada pada kategori baik dan 6 guru yang telah disertifikasi berada pada kategori sangat baik, jika dirata-ratakan 89,94 $\%$ berkategori baik.

Dilihat dari angket motivasi yang diisi oleh guru menunjukkan 13 orang guru berkategori setuju dan 17 orang guru berada pada kategori sangat setuju, ini menunjukkan adanya motivasi dalam menyusun RPP dengan lengkap, hal itu dapat dilihat pada penyusunan RPP pada siklus II dan siklus III.

Selanjutnya dilihat dari kemampuan guru dalam menyusun RPP, terjadi peningkatan dari siklus ke siklus, yakni: (1) komponen tujuan pembelajaran, pada siklus pertama 4 orang guru tidak membuat tujuan pembelajaran, jika dipersentasekan $13 \%$, pada siklus dua masih terdapat satu orang guru yang tidak membuat tujuan pembelajaran jika dipersentesekan $3 \%$ dan pada siklus ketiga, ketiga puluh guru tersebut sudah membuat tujuan pembelajaran, (2) komponen materi ajar, pada siklus pertama satu orang tidak menentukan materi ajar, karena tidak membuat RPP jika dipersentasekan 3\%, pada siklus kedua, ketiga puluh guru tersebut sudah menentukan materi ajar, (3) komponen metode pembelajaran, Pada siklus pertama satu orang guru tidak membuat metode pembelajaran, karena tidak membuat RPP, jika dipersentasekan 3\%, pada siklus ke dua, Ketiga puluh guru tersebut sudah membuat metode pembelajaran, (4) komponen sumber belajar, Pada siklus pertama satu guru tidak menentukan sumber belajar, karena tidak membuat RPP , jika dipersentasekan $3 \%$, pada siklus dua, ketiga puluh guru tersebut sudah menentukan sumber belajar (5) komponen penilaian ( soal, skor dan kunci 
jawaban), Pada siklus pertama 8 orang guru tidak membuat soal jika dipersentasekan $27 \%$, pada siklus kedua ketiga puluh guru tersebut sudah membuat Soal, terjadi peningkatan dari siklus pertama ke siklus dua $73 \%$. Selanjutnya 18 orang guru tidak membuat penskoran pada siklus pertama, jika dipersentasekan $60 \%$, Pada siklus kedua masih terdapat satu guru yang belum melengkapi komponen penilaian yakni penskoran, jika dipersentasekan $3 \%$, terjadi peningkatan $57 \%$. Pada siklus ketiga tidak ada perubahan, masih terdapat satu orang guru yang belum melengkapi penskoran pada salah satu RPP , Jika dipersentasekan 3 \%. Selanjutnya 25 guru tersebut tidak membuat kunci jawaban pada siklus pertama, jika dipersentasekan $83 \%$. Pada siklus kedua terjadi peningkatan hanya 4 orang guru yang belum melengkapi kunci jawaban, jika dipersentasekan $13 \%$ terjadi peningkatan dari siklus pertama ke siklus kedua $70 \%$. Pada siklus ketiga masih terdapat satu orang yang tidak membuat kunci jawaban dan nantinya akan dibimbing lagi oleh peneliti.

\section{KESIMPULAN}

Berdasarkan hasil penelitian dan pembahasan, maka dapat disimpulkan (1) melalui bimbingan berkelanjutan dapat meningkatkan motivasi guru dalam menyusun RPP dengan lengkap, Hal itu dapat dibuktikan dari angket motivasi yang diisi ketiga puluh guru tersebut nilai rata-rata $90,63 \%$ dengan kategori sangat setuju RPP dibuat dengan lengkap. Hal itu telah dibuktikan dari RPP yang dibuat, pada siklus satu sebagian besar guru tersebut belum melengkapi komponen penilaian, tetapi pada siklus dua dan tiga terjadi peningkatan . (2) melalui bimbingan berkelanjutan dapat meningkatkan kemampuan guru dalam menyusun RPP dengan lengkap. Pada siklus satu RPP yang dibuat pada umumnya pada komponen penilaian ( skor dan kunci jawaban ) belum lengkap, pada siklus dua dan siklus tiga terjadi peningkatan dalam menyusun RPP. Hal itu dapat dibuktikan dari hasil observasi /pengamatan memperlihatkan bahwa terjadi peningkatan kemampuan dalam menyusun RPP dari siklus ke siklus . Pada siklus satu rata-rata komponen RPP 72,57\% menjadi 97,29\% pada siklus dua terjadi peningkatan $24,72 \%$ dan pada siklus tiga rata-rata komponen RPP 99,14\%, terjadi peningkatan dari siklus dua ke siklus tiga $1,85 \%$.

\section{SARAN-SARAN}

Motivasi yang sudah tertanam terus dipertahankan dan dapat diimplentasikan dalam melaksnakan tugas, komponen RPP agar dibuat dengan lengkap, karna RPP sebagai acuan dalam mengajar, dokumen RPP minimal dibuat dua rangkap, satu untuk arsip sekolah dan yang satunya untuk guru yang bersangkutan. 


\section{DAFTAR RUJUKAN}

Arikunto, S., Safruddin,C. Jabar, A. (2004). Evaluasi Program. Jakarta: Rineka Cipta.

BSNP. (2007). Model Integrasi Pendidikan Kecakapan Hidup . Jakarta. Depdiknas

Depdikbud. (1998). Petunjuk Peningkatan Mutu Pendidikan di sekolah Dasar. Jakarta : Departemen dalam Negeri RI Dirjen. Pemerintah Umum dan Otonomi Daerah Kerjasama Departemen Pendidikan dan Kebudayaan Dirjen Pendidikan Dasar dan Menengah. Jakarta: Depdikbud

Depdiknas. ( 2005). Standar Nasional Pendidikan. Jakarta: Depdiknas.

Depdiknas. (2008). Pembinaan SMA, Jakarta: Depdiknas.

Depdiknas. (2009). Petunjuk Teknis Pembuatan Laporan Penelitian

Tindakan Sekolah Sebagai Karya Tulis Ilmiah Dalam Kegiatan

Pengembangan Profesi Pengawas Sekolah. Jakarta: DepdiknasDirjen PMPTK.

Kurniawati, E.D. (2009). Pengembangan Bahan Ajar Bahasa Dan Sastra Indonesia Dengan Pendekatan Tematis. Tesis Tidak

Dipublikasikan Surakarta: Program Pascasarjana Universitas Sebelas Maret.

Ali, I. 1995 Pembinaan Guru Di Indonesia. Malang: Pustaka Jaya.

Kumaidi. (2008). Sistem Sertifikasi (http://massofa.wordpress.com diakses 10 Agustus 2009).

Permendiknas RI, No. 41 Tahun 2007a. Tentang Standar Proses untuk Satuan Pendidikan Dasar dan Menengah, Jakarta: Depdiknas.

Permendiknas RI. No. 12 Tahun 2007b. Standar Pengawas

Sekolah/Madrasah. Jakarta: Depdiknas.

UU RI. ( 2003). Tentang Sistem Pendidikan Nasional.

UU RI. (2005). Tentang Guru dan Dosen. 